\title{
THYMOL AND CINNAMON OIL IN THE TREATMENT OF RINGWORM OF THE SCALP*
}

LYLE B. KINGERY, M.D.

Clinical Professor of Dermatology, University of Oregon Medical School PORTLAND, ORE.

At the annual meeting of the American Dermatological Association in 1924, uncler the title of "Mycotic Paronychia and Dermatitis," the results of a study demonstrating the etiology, pathology and symptomatology of what apparently was at that time a new clinical entity were reported. ${ }^{1}$ In addition, this investigation included the successful therapeutic management of the disease by the use of certain essential oils - a use apparently entirely new for a group of drugs long familiar in pharmacologic texts. Such a strikingly favorable therapeutic response on the part of a disease that is representative of a group containing many members refractory to ordinary remedies seemed worthy of further investigation. This was undertaken, and the results were reported at the meeting of this association three years later, in $1927 .{ }^{2}$ The latter study, while admitting the vast discrepancy often existing between laboratory experimentation and clinical application, still seemed to demonstrate a superiority on the part of the essential oils over timehonored remedies in their ability to kill and inhibit the growth of a large group of known nycotic invaders of the skin and viscera. With these experiences in mind, the former an apparent specificity with reference to a mycotic disease of the skin and nailbed, and the latter an undoubted fungicidal and fungistatic superiority in vitro, clinical trial in certain of the well known mycotic diseases seemed properly in order.

Before the advent of the use of the $x$-rays and thallium acetate, ringworm of the scalp presented perhaps one of the most unsatisfactory therapeutic problems. Treatment at best was prolonged and disagreeable, and in a considerable percentage of cases the cure was a spontaneous one at puberty. Begun by Freund ${ }^{3}$ in 1897 , improved by Sabouraud and Noire ${ }^{4}$ in 1904, and finally perfected as nearly as possible by MacKee, ${ }^{5}$

* Read at the Fifty-Second Annual Meeting of the American Dermatological Association, San Francisco and Del Monte, Calif., July 1-3, 1929.

1. Kingery, L. B., and Thienes, C. H.: Mycotic Paronychia and Dermatitis, Arch. Dermat. \& Syph. 11:186 (Feb.) 1925.

2. Kingery, L. B., and Adkisson, A.: Certain Volatile Oils and Stearoptens as Fungicides, Arch. Dermat. \& Syph. 17:499 (April) 1928.

3. Freund, L.: Wien. med. Wchnschr. 47:856, 1897.

4. Sabouraud, R., and Noire, H.: Presse méd. 12:825, 1904.

5. MacKee.: X-Rays and Radium in Treatment of Diseases of the Skin, Philadelphia, Lea \& Febiger, 1921, p. 602. 
roentgen treatment now offers a management of these cases which has made the disease a rarity in some localities in which formerly the infection was constantly present in considerable numbers. This method of treatment, however, is still a highly technical procedure; it is difficult to carry out in the extremely young, and in spite of every precaution roentgen injuries still occasionally occur.

Somewhat similar comment may be made on the treatment with thallium acetate. Unquestionably, tremendous strides have been made with the use of thallium acetate since Buschke's ${ }^{6}$ experimental report in 1900. Not only has he continued to add to the knowledge of this particular use of the drug, but others, including Cicero ${ }^{7}$ and Peter, Ritter ${ }^{8}$ and Art $z,{ }^{10}$ have likewise made important contributions. That the drug is highly successful in certain hands is shown more recently by the comprehensive report of Felden. ${ }^{11}$ Yet with this, as with roentgen therapy, there are possible objections. The dosage must be computed with extreme accuracy ; increasing dangers exist as the age of the patient nears puberty; reactions of various types are not unknown, and even permanent undesirable effects are occasionally recorded.

With these points in mind relative to the present methods of treatment, and encouraged by the clinical trial and laboratory experiences alreacly related, the following study was undertaken. In it are included twelve cases of ringworm of the scalp in patients seen between October 1927, and November, 1928, in private practice and in the dispensary. With the exception of one case presenting acutely painful and inflammatory pustular lesions, the group represented clinically the Microsporon type of invasion. With two exceptions, the clinical diagnosis was substantiated by microscopic examination. In these two, there is no record of this having been done. The patients are representative of every social status. Each patient has been treated in practically the same manner. The measures carried out were as follows:

1. Clipping of the hair to the extent of $1 \frac{1}{2}$ inches $(3.8 \mathrm{~cm}$.) around the border of the lesions when only one or two lesions were present.

2. Clipping of the hair of the entire scalp when the disease was generalized.

6. Buschke: Experimenteller Beitrag zur Kenntnis der Alopecie, Ber1. klin. Wchnschr., 1900, no. 53 , p. 1235 .

7. Cicero: Tratamiento de las tinas por el acetato de talio, Rev. de puebla 1919, no. 8; reference in Peter: Secundo congreso sudamericano de dermatologia y sifiligraphia de Montevideo, Arch. f. Dermat. \& Syph. 150:438 (Oct.) 1921.

8. Peter: Arch. f. Dermat. u. Syph. 150:438 (Oct.) 1921.

9. Ritter: Dermat. Gesellsch., February, 1927; reference in Dermat. Wchnschr. 85:955, 1927.

10. Artz: Wien. Dermat. Gesselsch., January, 1927; reference in Dermat. Wchnschr. 84:834, 1927.

11. Felden, B. F.: Epilation with Thallium Acetate in the Treatment of Ringworm of the Scalp in Children, Arch. Dermat. \& Syph. 17:182 (Feb.) 1928.
3. Constant wearing and frequent changing of a washable cap.

4. Biweekly soapsuds shampoo.

5. The application three times daily of a solution of gutta percha B. P. C., ${ }^{12}$ containing one half of 1 per cent thymol and 1 per cent oil of cinnamon. In cases in which this resulted in irritation, the frequency of the applications was decreased.

Early results of the foregoing treatment are shown in table 1. A brief analysis of this table would seem to emphasize a single outstanding

\begin{tabular}{|c|c|c|c|c|c|c|c|c|}
\hline Case & Source & Eruption & Duration & Age & $\operatorname{sex}$ & $\begin{array}{c}\text { Treatment } \\
\text { Begun }\end{array}$ & $\begin{array}{c}\text { Last } \\
\text { Examina } \\
\text { tion }\end{array}$ & $\begin{array}{l}\text { Apparent } \\
\text { Impediate } \\
\text { Restints }\end{array}$ \\
\hline 1 & $?$ & 2 lesions & $\begin{array}{c}\text { Several } \\
\text { weeks }\end{array}$ & $2 \frac{1}{2}$ yrs. & $\mathrm{M}$ & $12 / 12 / 27$ & $3 / 28 / 28$ & 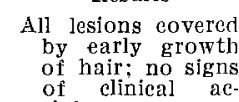 \\
\hline 2 & Scbool & Multiple & 6 wks. & $6 \mathrm{yrs}$ & $\mathrm{M}$ & $12 / 28 / 27$ & $3 / 15 / 28$ & $\begin{array}{l}\text { tivity } \\
\text { Completely invo- intel ing } \\
\text { luted, lair com } \\
\text { pletely }\end{array}$ \\
\hline 3 & ? & Multiple & $3 \mathrm{mos}$. & $6 \mathrm{yrs}$. & $\mathrm{M}$ & $1 / 25 / 28$ & $4 / 30 / 28$ & $\begin{array}{l}\text { Completely invo- } \\
\text { lutet; hair com- } \\
\text { pletely returned }\end{array}$ \\
\hline$t$ & ? & Multiple & $\begin{array}{l}2 \text { to } 3 \\
\text { months }\end{array}$ & $21 / 2 \mathrm{yrs}$ & $\mathrm{M}$ & $2 / 3 / 28$ & $4 / 15 / 28$ & 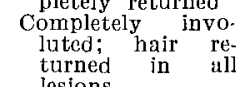 \\
\hline 5 & Dog? & Single & 1 week & 22 mos. & M & $2 / 14 / 28$ & $3 / 14 / 28$ & $\begin{array}{l}\text { Completely invo- in } \\
\text { luted: no inflam } \\
\text { matory raction; } \\
\text { hair returning in } \\
\text { lesions }\end{array}$ \\
\hline 6 & Dog & Multiple & $1 \mathrm{mo}$ & $\pm \mathrm{yrs}$ & $\mathrm{M}$ & $3 / 1 / 28$ & $3 / 10 / 28$ & $\begin{array}{l}\text { Infammation sub- subs } \\
\text { siding; no signs } \\
\text { of clinical activ- }\end{array}$ \\
\hline 7 & $\begin{array}{l}\text { Other } \\
\text { children }\end{array}$ & Multiple & $\begin{array}{l}\begin{array}{l}3 \text { to } 4 \\
\text { weeks }\end{array} \\
\text {. }\end{array}$ & $3 \mathrm{yrs}$ & $\mathrm{F}$ & $8 / 11 / 28$ & $8: 20 / 28$ & $\begin{array}{l}\text { Intlymatory re- } \\
\text { action subsiding } \\
\text { netion pusiong }\end{array}$ \\
\hline 8 & Persian & Single & 4 wks. & $7 \mathrm{yrs}$ & $\mathrm{F}$ & $9 / 4 / 28$ & $10 / 2 / 23$ & clinically inactive: \\
\hline 9 & , & Single & $7 \mathrm{wks}$. & 3 yrs. & $\mathrm{F}$ & $9 / 4 / 28$ & $11 / 22 / 28$ & $\begin{array}{c}\text { no new lesions } \\
\text { Clinically inactive; } \\
\text { no new lesions }\end{array}$ \\
\hline 10 & School ? & Multiple & $\begin{array}{l}\text { Several } \\
\text { weeks }\end{array}$ & $7 \mathrm{yrs}$ & $\mathrm{F}$ & $10 / \overline{5}: 28$ & $10 / 11 / 28$ & $\begin{array}{l}\text { Clinically, some } \\
\text { improvement: } \\
\text { microscopopicaliy } \\
\text { negative (dispen. } \\
\text { sorry) }\end{array}$ \\
\hline 11 & ? & $\begin{array}{l}\text { Multiple } \\
\text { lesions; } \\
1 \text { keríon }\end{array}$ & $2 \mathrm{mos}$ & $7 \mathrm{yrs}$ & $\mathrm{F}$ & $11 / 22 / 28$ & $1 / 26 / 29$ & $\begin{array}{l}\text { clinieally inactive; } \\
\text { no inflammation; } \\
\text { microscopieally }\end{array}$ \\
\hline 12 & Cat & Single & $4 \mathrm{wks}$. & 4 yrs. & $\mathrm{M}$ & $11 / 22 / 28$ & $1 / 12 / 29$ & $\begin{array}{l}\text { No clinieal activ. } \\
\text { ity; hair return } \\
\text { ing on all } \\
\text { patclles; milros. } \\
\text { copically negative }\end{array}$ \\
\hline
\end{tabular}

point of interest, that of a uniformly favorable response to treatment In case 11 the patient presented numerous lesions over the scalp, one definitely of the kerion type. Treatment was augmented in this case by boric compresses applied three times daily. Response to treatment was nuch the same in all the other cases. At the time of the first weekly

12. The solution is composed of gutta percha $10 \mathrm{Gm}$., lead carbonate $10 \mathrm{Gm}$., chloroform to make $100 \mathrm{Gm}$. After thorough agitation decant the clear liquid. The preparation is therefore a solution of gutta percha in chloroform. 


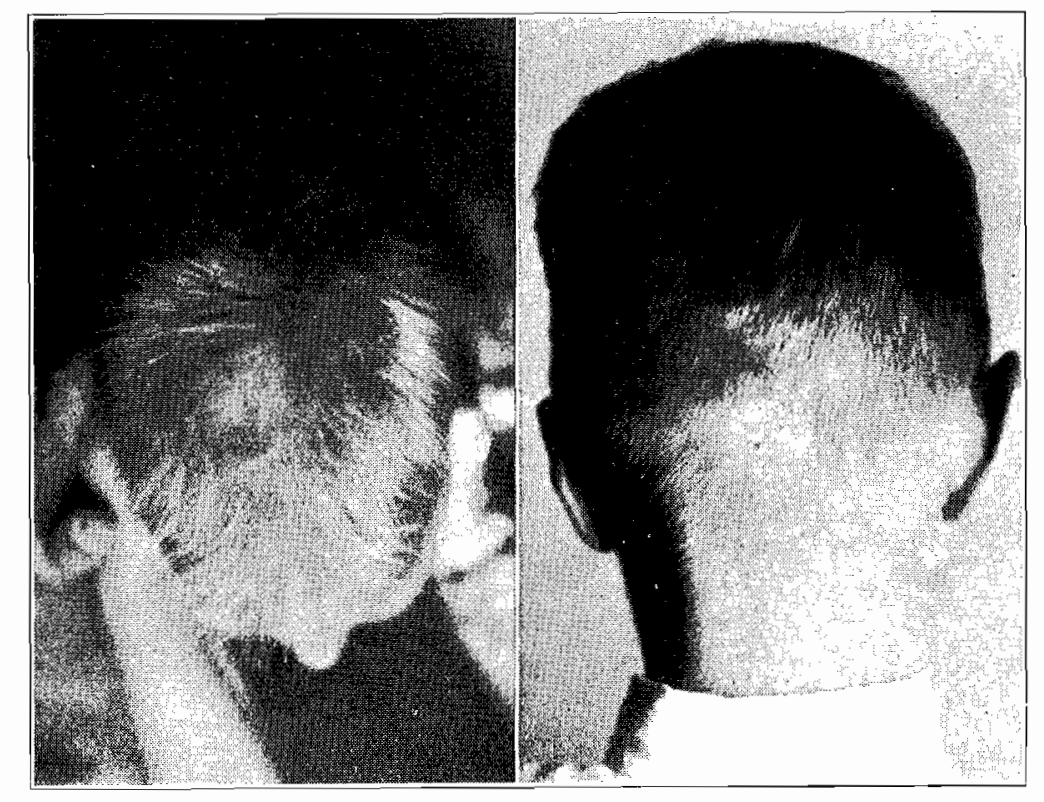

Fig. 1 (case 3).-Appearance at time of first examination (small lesions due to pyogenic infection).

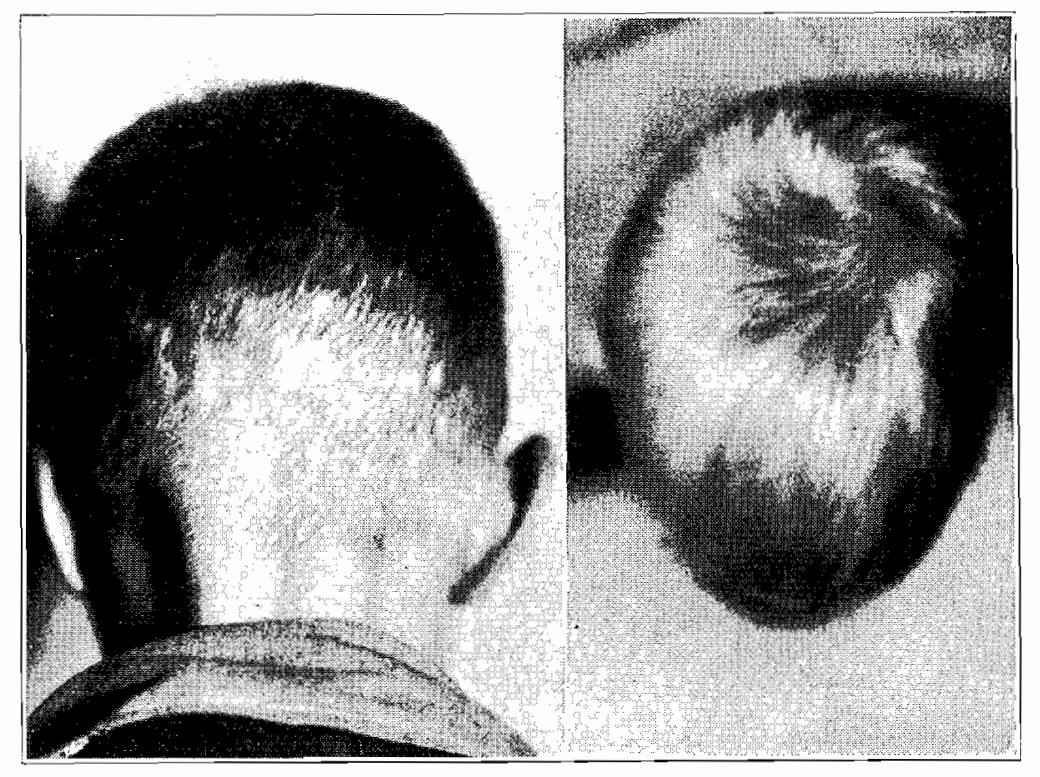

Fig. 2 (case 3).-Appearance four months later. observation, practically every case showed a definite cessation of activity. In no case were new lesions encountered. Inflammatory reaction was rapidly disappearing, and formerly active lesions gave definite clinical signs of regression. Subsequent observations made regularly or otherwise, according to the type of patient, revealed a continuation of these signs of involution. Some patients were seen twice a week and others weekly, for a period of from eight to ten weeks. The course seemed much the same in all cases; i.e., early regression and a continuation of involution until complete restoration of hair was obtained.

Being familiar with the tenclency to recurrence and the ease with which many apparent cures may change in a few weeks to a repetition of the original involvement, a further effort was made definitely to estab-

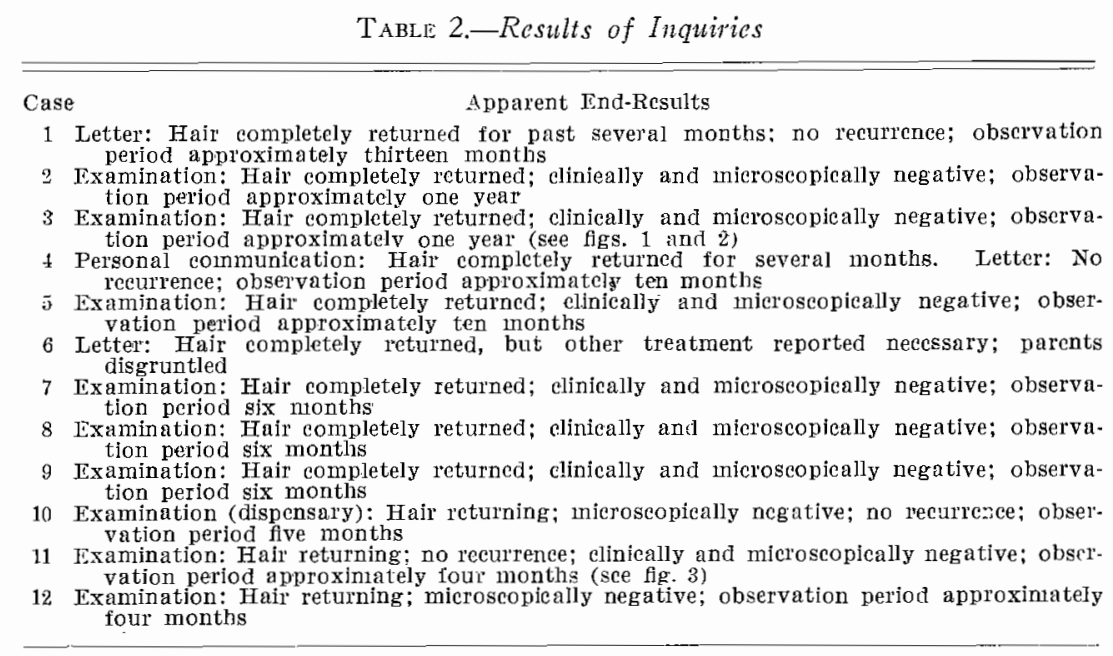

lish apparent clinical cures which seemed assured at the last opportunity of seeing the patient. With this in mind, follow-up letters were sent to the parents of each patient in the series. In these letters, the parents were earnestly requested to return the patient for personal examination. When this was impossible, they were asked to answer the following questions:

1. Did the eruption completely heal under the treatment given?

2. How long was the child treated?

3. Has the condition ever reappeared?

4. Were other medicines used? If so, what?

5. Does the scalp appear entirely healthy now?

6. Has all of the hair returned?

The results of these inquiries are seen in table 2. Analysis of this table would seem to furnish still further encouraging information. Primarily, one failure is noted; case 6 which, according to table 1 , seemed to give promise of favorable response after ten days' treatment, 
is reported as a complete failure necessitating the use of other remedies. In addition, the mother expressed definite personal dissatisfaction at the general conduct of the case. Apparently, therefore, the question of treatment and cure must remain in doubt, as a personal exanination was impossible. It is to be noted further that it was possible to examine eight of the remaining patients microscopically, with uniformly negative results. The children had complete restoration of hair, and these findings had existed at periods varying from one year to four months after treatment was begun. For various reasons, the three remaining patients

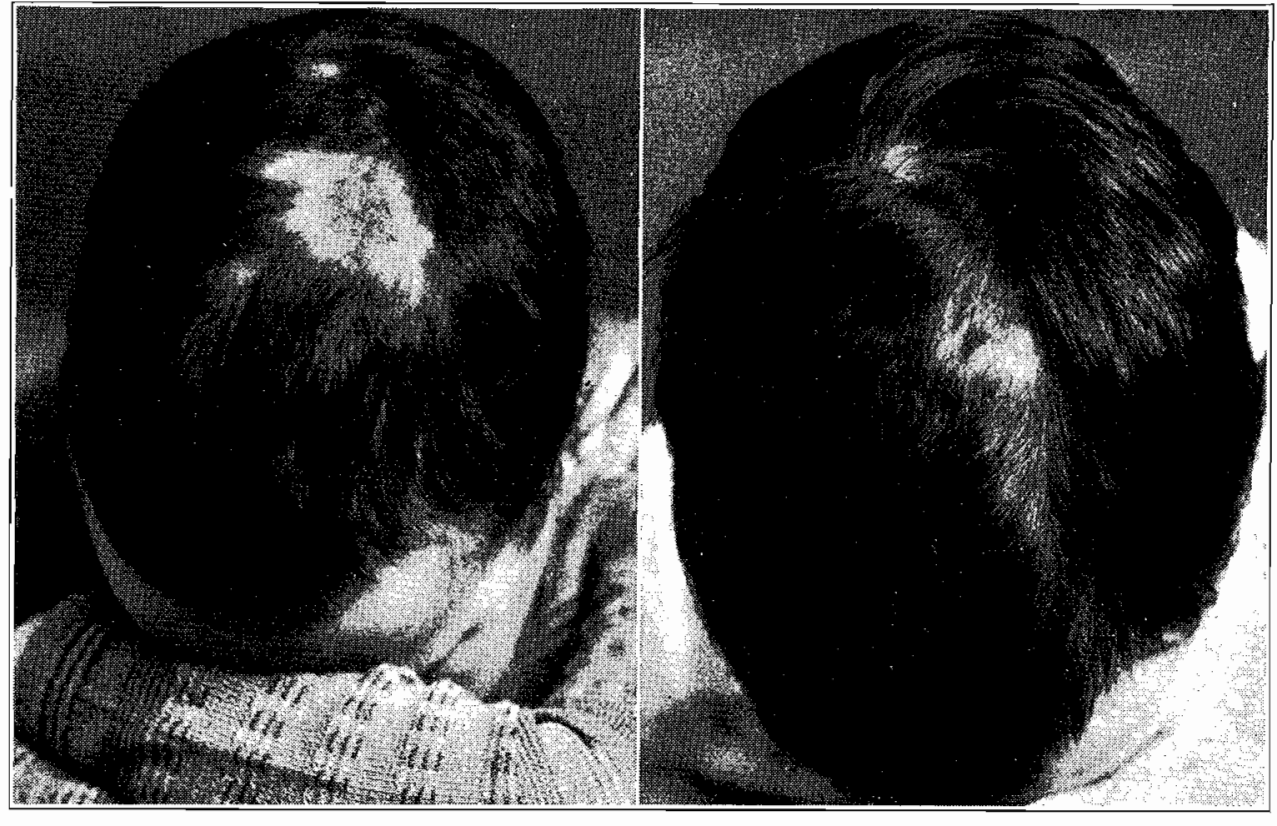

A

B
Fig. 3 (case 11). $-A$, appearance two weeks after treatment was begun. The large lesion, which was of the so-called kerion type when first seen, is now rapidly involuting. $B$, light scarring by previous pustular lesions; otherwise, the hair is returning over all the lesions. This picture was taken two and one-half month after $A$

could not be brought to the office. Personal communication with the parents, however, established the facts that no other treatment had been used, that clinical cure, including complete return of hair, had taken place, that there had been no recurrences and that these restilts had existed for a period varying from one year to four months. It would not seem unfair, therefore, to assume that in these patients, as well as in those examined microscopically, clinical cure had occurred.
COMMENT

In the foregoing paragraphs are related the results of treatment of twelve patients with tinea capitis treated exclusively with thymol and cinnamon oil. Eight were clinically and microscopically well in periods varying from four months to one year; three, according to letters from the parents, have enjoyed complete restoration of hair and no recurrence of symptoms over approximately equivalent periods. In the light of our present knowledge of the disease, it would seem fair to assume that these, likewise, were clinical cures. In the remaining case the mother of the patient, in spite of an apparently favorable response while under observation, reports the necessity of using other remedies. As far as it has been possible to learn, in no case has there been a permanent alopecia and the remarkable simplicity of the method obviates any necessity of discussing the possibilities of temporary or permanent untoward effects. Whether or not this method offers advantages over that suggested by Lieberthal ${ }^{13}$ or the older, more complicated methods of treatment remain for a more comprehensive clinical trial to determine. Yet data furnished herein would seem to merit the method favorable consideration and more wiclespread clinical application.

\section{CONCLUSIONS}

1. In this paper are related the results of a clinical trial of clrugs the fungicidal and fungistatic activities of which were previously demonstrated in vitro.

2. This trial would seem to furnish presumptive evidence of a similar activity so far as ringworm of the scalp is concerned.

3. While the evidence provided is far too limited to be exclusive, should the above experience be duplicated in other clinics and with a greater variety and number of cases, it would seem that this simple method of treatment might well stand favorable comparison with the older and more complicated ones now in vogue.

13. Liebertha1, E. P.: Treatment of Microsporen Infection of the Scalp Arch. Dermat. \& Syph. 18:97 (July) 1928 